\title{
ON OUR CLASSIFICATION AND TREATMENT OF CANCER OF THE MAXILLA
}

\author{
By \\ SYUNICHI SAKAI \\ From the Department of Otorhinolaryngology Osaka University \\ Medical School (Director: Prof. T. Hasegawa) \\ YASUSHI $_{\text {HAMASAKI }}$ \\ From the Department of Radiology Osaka University \\ Medical School (Director: Prof. H. Tachiiri)
}

1) Of the total 161 cases of cancer of the maxilla which were diagnosed in our hospital, 115 cases were treated according to our approach and the remaining 23 cases received conservative treatment alone. All cases was followed up for more than one year.

2) We estimated the size and the direction of extension of the tumor mainly from X-ray findings, and later necessary corrections were added with operative findings.

3) Six types were classified according to the presumptive site of origin. According to the direction of extension, antral type was divided into 5 types in frontal (plane (medio-superior, laterosuperior, medio-inferior, latero-inferior and antrum diffuse and into 4 types in sagittal plane (central, anterior, posterior and bipolar). Size of the tumor was expressed in 4 grades (localized, relatively localized, extensive and highly extensive).

Presence or absence of metastasis was also mentioned.

4) $98 \%$ of all cases was the type of antral origin, among which relatively localized type was $33 \%$, extensive type $61 \%$, medio superior type $36 \%$ and antrum diffuse type $39 \%$.

Metastasis, wich was present in $16 \%$ of all cases, was associated in comparatively higher percentage with medio superior, antrum diffuse and posterior types.

5) Routinely employed policy of treatment in our hospital was preoperative irradiation, total resection of maxilla and postoperative intracavitary irradiation, with the exception of radiation therapy alone for inoperable and in cases where the operation was refused.

6) When treated in our routine sandwich method, three year survival rates for relatively localized and extensive types were $40 \%(4 / 10)$ and $33 \%(3 / 9)$, respectively.

The former, when treated with radiation alone, showed three year survival rate of $36 \%(4 / 11)$. Thus, the results fall within the range of 30 to $40 \%$.

When the extensive type was treated with radiation alone, three year survival rate of $12 \%$ $(3 / 25)$ was obtained. Over-all three year and five year survival rates were $24 \%(14 / 58)$ and $36 \%$ (5 14), respectively.

7) It is felt that closer cooperation of surgeons and radiologists is essential to attain better therapeutic results. 


\title{
上顎癌の分類と治療方針について
}

\author{
大阪大学医学部耳器咽喉科学教室（主任：長谷川高敏授） \\ 酒 茾俊
}

大阪大学医学部放射線医学教室（主任：立入弘教授）

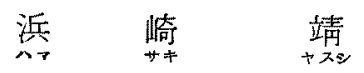

\section{緒 霉}

上顎癌の分類は, Sibileau (1906)1), Öhngren (1933)

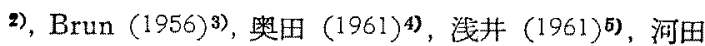
(1962)6)等によりなされているが，これらは主に手術所 見によるるのである. 一方, Baclesse (1952)7), Dodd $(1959)^{8)}$ 及び著者の一人浜㱦 $\left.(1961)^{9}\right)$ はX線所見に上 る分類を行つた，最近断層撮影法を体系的に採用子るこ

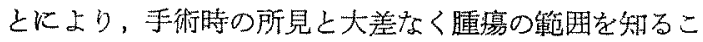
とが可能となつたので，上顎壆の分類は，治療前のX線 所見によることを原則とし，手術症例については後日必 要に心じて補正を加兑る力式が適切であると考充，䈍者 らはその見地から分類を試みた。

一般に悪㤬腫疖の分類は，次の目的からなされてい 万.

1) 統計的観繁を行与.

2) 予後あるいは転移を推定する。

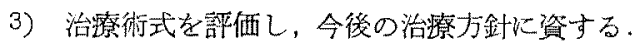

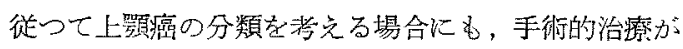
治療の本肪とされた時代は過ぎ云つて，優秀な放射線治 療が発達した今日に执いては，上記の1）2）6大切で はあるが，臨床医家の立場からは3の目的がより重要 なるのとなつてくる，分類に閔する過云の文献をみる と，2ないし4に分類する簡略なものから，上顠洞を6

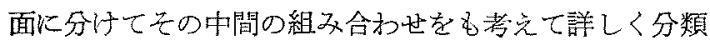
するものなど種ふであるが，著者らは，余りに簡略では

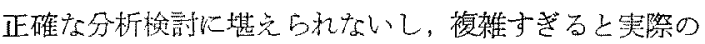

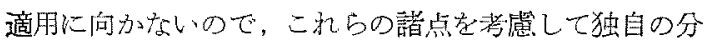
類を作成しだ。

上䞄癌の治療兮針についてみると, 手術, 放射楾, 化 学療法等があるが,わが国において, 現在の所研究者去

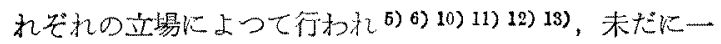

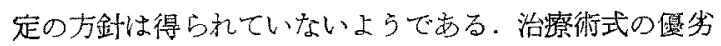
は，精確に集計されてた定例の遠原成績をみなけれい゙判明 しないけ狄ども，调士の文献では，あるいは早期限局症
例のみを選んでいるように思われるもの, 症例数が少い むの，まるいは症例数は多いが消息不明例も多くて精確 な追跡がなされていないもの，成續の中に1年末满症例

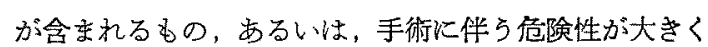
て医潦偷理に合わないものなど著者らの納得でさるるの が少㔚かた。

しかし, Larsson, Märtensson (1954)14) は, 術前炤 射，手術 (上頍全剔術)，腔内照射の三者を併用し，114 例につき5年治痕率 $45 \%$ の好成績を出し, 放射線単独 療法行つた日の毛含めて, 全症例 256 例につき 5 年治 瘁率 $27 \%$ の成績を酦告した，この三者侣用療法に基す く治療遠隔成績が䐴秀であることは云うまでもないが， その治潦方針特に術前职射扣よび放射線単独療法は現在

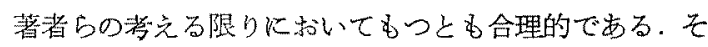
の根扰については，

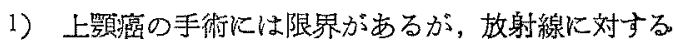
感受性が比較的高いので，両者を併用すれば，単独潦法 よりも成績の问上が期街できる。

2)術前放射線治療を行うことは，術後昭射を行らよ 门も，酸素効果の理論等から考えてより効果的である。

3）術前照射を行つて扣くことは，手術に際し，睡瘍

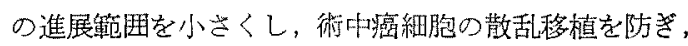
組織の瘵痕化により手術操作を容易にさせる。

4)小線源使用による適切な術後腔内照射法は，照射 期間を短縮し，患者の全身娈碍を゙少くして局所の線量を 大とすることができる。

5) 広沉進展淀例の場合に，いわゆる広沉手術によつ て多数の嬁牲の上に少数の患者の生命を数らよりる，放 射線単独療法に上つて全患者の延命効果を期待方方

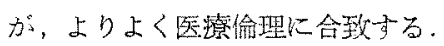

患者らは, 以上の钼点から上顎癌の治撚方針としてこ の三者併用痁法（俗称サンドウイッチ法）を採用し，手 術不能例や手術拒否例に刘しては，経皮的放射線単独療 法を行らことにしだ). 昭和 32 年1月より開始したが、 
㷖和 37 年 6 月末現在，かなりの症例数化達し，治潦方 針について大体の見通しをつけることができたのでここ 比報告し，諸賢の御批判を仰ぐ次第である。

\section{対 象 例}

今回の発表汇際して取扱われている患者対象は，昭和 32 年 1 月上り，昭和 36 年 6 月まで 4 年 6 力月間に，大 阪大学医学部附属病院耳鼻咽知科および放射線科を訪九 た上顎癌患者のらち，組織所見が確定し，著者らの検査 術式によるX線撮影法も採用し得て䜌断した症例 161 例 である、この中には，肉腫その他の悪性腫瑒は含まず， 腯腫のみに限定されている。

これを年次別にみると第1表の如くである.

第 1 表 上顎癌患者の年次别分枟

\begin{tabular}{|c|c|c|c|c|c|}
\hline \multicolumn{2}{|c|}{ 年 } & \multicolumn{2}{|c|}{ 次 } & \multirow[t]{2}{*}{ 例 } & \multirow{2}{*}{$\frac{\text { 数 }}{32}$} \\
\hline 炤 & 和 & 32 & 年 & & \\
\hline 昭 & 和 & 33 & 年 & & 31 \\
\hline 昭 & 和 & 34 & 年 & & 30 \\
\hline 昭 & 和 & 35 & 卧 & & 44 \\
\hline \multicolumn{4}{|c|}{ 昭和36年（6月立で） } & & 24 \\
\hline & & & & & 161 \\
\hline
\end{tabular}

第 2 表 上影癌腎者 161 名の経過大別

A）経過明らかなるの

a）著者らの計画した治潦を溫行したもの 115

1) 現在生存

2）癌矣のため死亡

3) 掉故死

b）放置南るいは姑息的治療しか行兄ず

c）地医にて治療を受けたもの

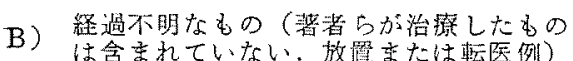

次に，経過の明，不明に上り大別すると，第 2 表の上 らになる，当院で治療を行つたものについては，全て満 1 年以上経過を追跡することができているが，経過不明 例は放置あるいは他医にて治療されたと見做される症例 である。

\section{$\mathbf{X}$ 線撮影法}

著者らが日常に上颚㾇患者に採用しているX線撮影法 は、既汇詳しく述べだが，
1) 正 前
2) Waters
3) 半軸方向
4) 軸方向

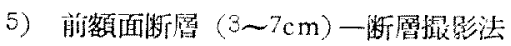

等である.

以上の各撮影法を体系的に採用し，渗潤籍围について， 正確なX線䀐断を照射前に行らのを原則としている。

\section{分 類 法}

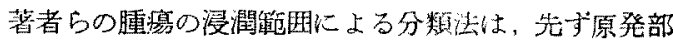
位別，その中，上買洞原発のものについて，進展方 向，程度，更に転移の有無別を考虑している。

原発部位別に及ると，上频洞，節胃䗋策，蝶形洞，前

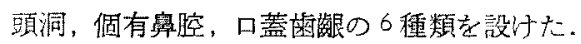

上顎洞原発については，前額面に関して，上内力，上 側方，下内方，下側方，洞中心の5 種類を，前後軸阔関 しては，前後になし，前方，後方，前後ともの4種類を 設けた。

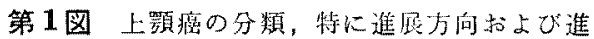
展程度の略図(右侧比限的限局型之左㑡広沉型) 上 4 図は $5 \mathrm{~cm}$ 断㬝, 前方型は $3 \mathrm{~cm}$ 断聠，後 方型は $7 \mathrm{~cm}$ 断尿, 半軸方向, 粗方向の Schemaである。

$$
\text { 上中方型 }
$$

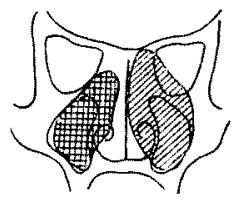

下内方型

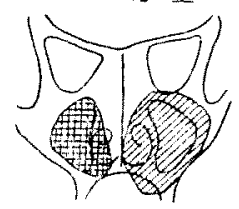

前方型

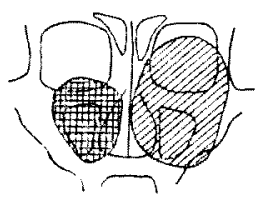

良方型

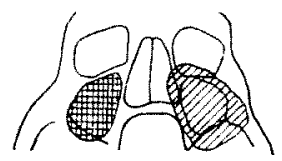

上㑡方列

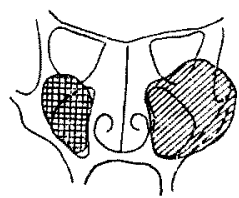

下側方型

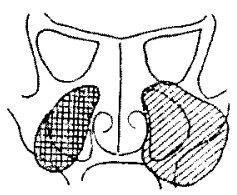

绫方型

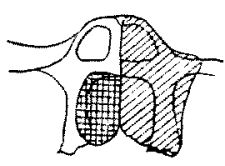

保方

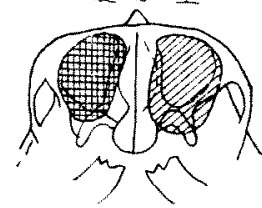


進展程度別は，限局，比較的限局，広沉，超広沉の4 種類を設けたが，進展方向により夫々の意味も異なるの で各撮影法との関連について第1図に示した。しかし， その概念は，

限局：骨破壞のないもの

比較的限局：骨破墂はあるがー次的手術の可能なるの 広沉：骨破唗があり，一次的手術のや小困難なる。

超坉沉：頭蓋底，反対側への漫潤高度のため手術不可 能度もの

等である。

転移については，有無とその部位によつて記した。

\section{分類成績}

上記の対象 161 名について，著者らの分類法に従つて 分類すると，第3〜6表の通りになる。

腫瘍分類の主目的は，既述したよらにその予後を推定 するのであるから，各型每に生存率，生存期間等を検討し なければならない，これらの分類と予後との関連をみる と、表には示さなかつたが，進展方向別に上り著差を認 めず, 程度別には比較的限局, 広沉, 超広汎の順に不良 となつている。転移に関して，上記の 1 年以上観察例に ついてみると，転移を認めた症例は25 例で，淮展方向 別，程度別分布は，第6表に示した。これによると，上 内方，洞中心型に集中し，他の型に発見されなかった点
は注目すべきである。

以上の分類成績から，いわ师る上䫇澏は，上顎洞原発 型が大部分であること，限局型は少数で，試験開放等に よつて偶然に発見されるものであり．広沉型になつて受

第 3 表 原笔部位別分類

\begin{tabular}{|c|c|c|c|c|}
\hline 原 & 発 部 & 位 & 例 & 数 \\
\hline 上 & 靧 & 洞 & 157 & $(98 \%)$ \\
\hline 笘 & 骨 䗋 & 窠 & 0 & $(0 \%)$ \\
\hline 蝶 & 形 & 洞 & 0 & $(0 \%)$ \\
\hline 前 & 賈 & 洞 & 0 & $(0 \%)$ \\
\hline 固 & 有 舜 & 腔 & 2 & $(1 \%)$ \\
\hline 口 & 趾 崡 & 欲艮 & & $(1 \%)$ \\
\hline & & & 161 & \\
\hline
\end{tabular}

第 4 表 谁路程庭別分類

\begin{tabular}{|c|c|c|c|c|}
\hline 進 & 国 程 & 度 & 例 & 数 \\
\hline 限 & & 局 & & $(0,6)$ \\
\hline 比 & 较 的 限 & 局 & 53 & $(33 \%)$ \\
\hline 広 & & 沉 & 98 & $(61 \%)$ \\
\hline 超 & 広 & 沉 & & $(6 \%)$ \\
\hline & & & 161 & \\
\hline
\end{tabular}

第 $\mathbf{5}$ 表 上须洞原発型の進展方向別拉よび進展程度別分類

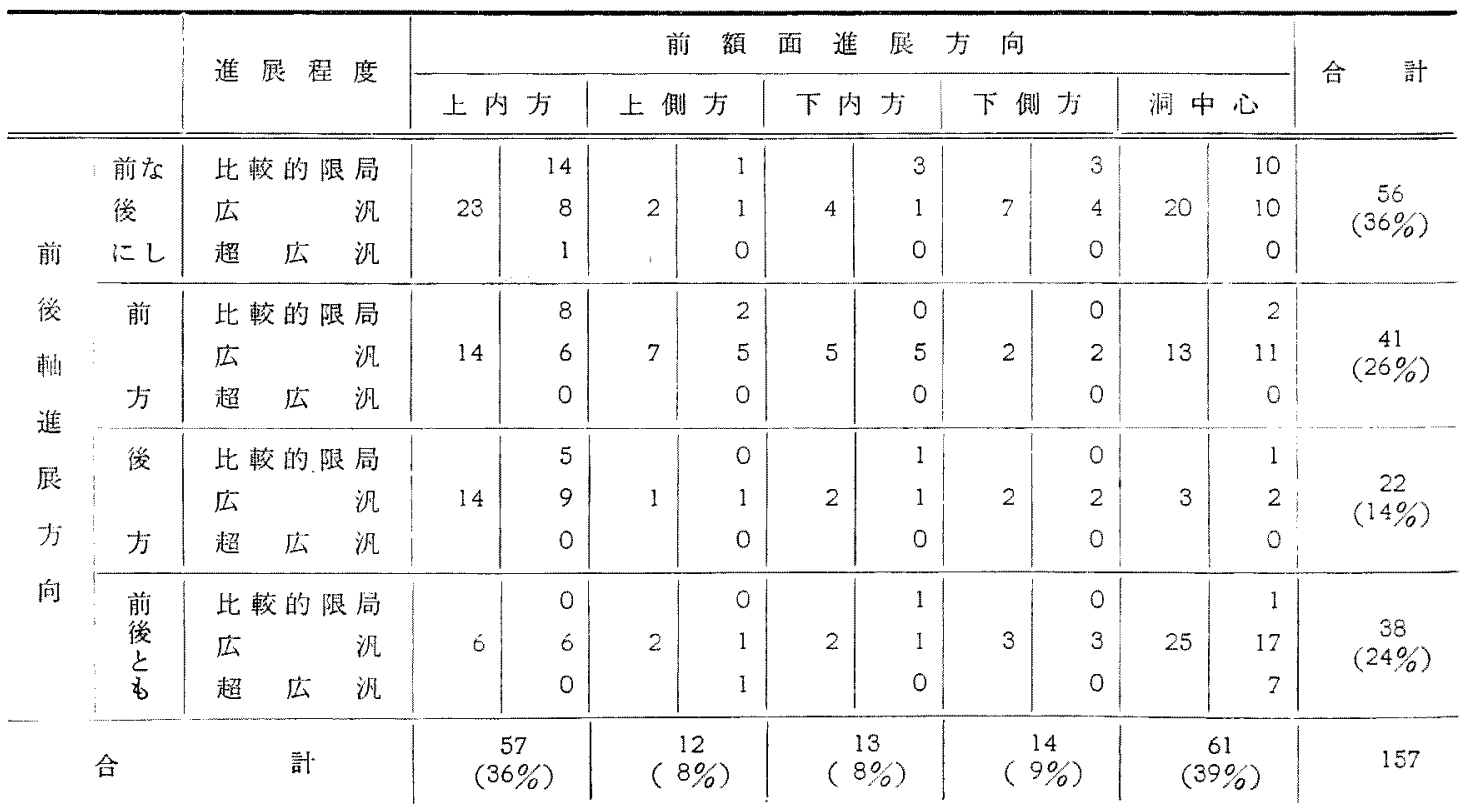


第 6 表 分類と鞋移との関連

\begin{tabular}{|c|c|c|c|c|c|c|c|c|}
\hline $\begin{array}{c}\text { 耺移 } \\
\text { 部位 }\end{array}$ & 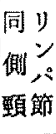 & 反将 & 脯 & 骨 & $\begin{array}{l}\text { 全 } \\
\text { 身 }\end{array}$ & $\begin{array}{l}\text { リ 行 } \\
\text { ソ } \\
\text { パ性 }\end{array}$ & $\begin{array}{l}\text { 血 } \\
\text { 行 } \\
\text { 性 }\end{array}$ & $\begin{array}{l}\text { 合 } \\
\text { 僦 }\end{array}$ \\
\hline 数 & 14 & 6 & 8 & 5 & 2 & 14 & 13 & $25(16 \%)$ \\
\hline 上内方 & 5 & 1 & 5 & 4 & 2 & 5 & 9 & $16(28 \%)$ \\
\hline 上僛 方 & 0 & 0 & 0 & 0 & 0 & 0 & 0 & 0 \\
\hline 下内方 & 0 & 0 & 0 & 0 & 0 & 0 & 0 & 0 \\
\hline 下側 方 & 0 & 0 & 0 & 0 & 0 & 0 & 0 & 0 \\
\hline 洞中心 & 9 & 5 & 3 & 1 & 0 & 9 & 4 & $13(25 \%)$ \\
\hline 個有舫腔 & 1 & 0 & 0 & 0 & 0 & 1 & 0 & $1(50 \%)$ \\
\hline 前挠になし & 5 & 3 & 1 & 1 & 2 & 5 & 3 & $9(16 \%)$ \\
\hline 方 & 1 & 0 & 0 & 1 & 0 & 1 & 1 & $2(6 \%)$ \\
\hline 後 & 0 & 1 & 4 & 1 & 0 & 1 & 4 & $6(26 \%)$ \\
\hline 前後と6 & 7 & 2 & 3 & 2 & 0 & 7 & 5 & $12(26 \%)$ \\
\hline 比限 局 & 5 & 2 & 3 & 2 & 1 & 5 & 4 & $9(16 \%)$ \\
\hline 厸 㲸 & 7 & 4 & 5 & 3 & 1 & 7 & 9 & $14(14 \%)$ \\
\hline 超広沉 & 2 & 0 & 0 & 0 & 0 & 2 & 0 & $2(22 \%)$ \\
\hline
\end{tabular}

但し（）内は管々の整症例に刘する耺移の 百分蜜を示す○は転移の発見されなかつたこ とを示す

影するるのが多いこと, 進展方向型には，上内力，洞中 心型が多いこと，転移は1年以上絽滑観祭により25 例 に認められ, 上内方, 洞中心, 後方, 前後と60各型に 多発すること等の諸点が判明した。

\section{治療方針}

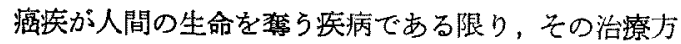
針が漓尰を完全に除去し，患者の生命を守る方向一占け られるべきことは論をなたない、しかし，些在するのは 病気ではなく病人であることに思い老致すとき，その治 療方針が単に技術的な面だけに終止することなく更に広 い視野が要求されることが判る、著者らの喼者のうち， 手術を受けた1人は顔面の䣨形を悲钼して，自ら生命を 絶つたことがあつたが，これは，著者らの治轑方針が完 全に失敗であつたことを反省させてくれた。医潦とは， 苦しも病者に救助の手を美しのべるといら本来的に人道

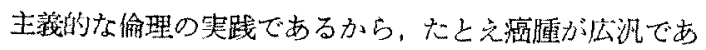

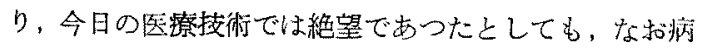
者の心に救いを与支ることに孥打せ杖ならない、従つ て，事夷発見とか，研究熱心の余り医師が治潦の限界夌 越えて患者に不当な犠牲巵険性を負わせることは，技倷 の未熟あるいは事なかれ主载による姑息的治潦を綂ける
ことと同様に大きな罪覀であるといわ秋ばならない、医 師が裂をもち，全人格を打ち込んで医療に対処するなら ば，ての上らな罪は犯さないであるらし，とのような衙

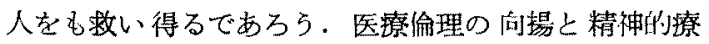
法，㭧者の協力は，治滰方針を論じ乿行するに当つて決 して等闌に付してはならない問題である。

次に狭義の治療方針としては緒焉で螌れて扣いたが， 昭和 32 年1月より，昭和 35 年 10 月まで，著者らは以 下の術式以徒つて治療を行つた。乙れ以降は，治療装置

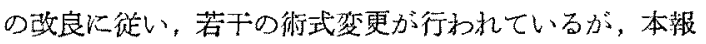
告に述べられた治療成績は以下の術式によるむの上考え て差支京小い。

I）比較的限局型，広沉型の場合. 術前昭射，上 颚全剔術，腔内照射の三者併用 ${ }^{15)}$

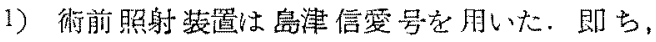
$200 \mathrm{kVp} \mathrm{X}$ 線， $15 \mathrm{~mA}, 0.9 \mathrm{Cu}+0.5 \mathrm{Al}$ 攵鬳焦点間距猚 $50 \mathrm{~cm}$, 炤射里は，上方眼军上縁か、ら下方上口唇までとす る. 従つて, $10 \times 6 \mathrm{~cm}^{2}, 10 \times 7 \mathrm{~cm}^{2}$ で, 前方 2 門，側方 2 門，郡4 阴の固定照射定行い，1日1閔射で1回の 照射蜾は250〜300レントダン（空帅）とし，各門2000

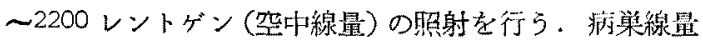
は約 4000〜4500レントゲンとなり，期閻は䄪 5 䓢間と

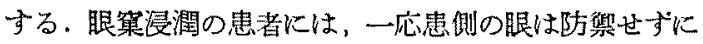
照射を行弓，その後，顔面の友虏炎消退，全身状態の恢

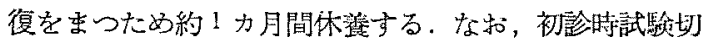

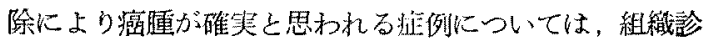
判明を待たずに直らに昭射を開始与ることにしている。

2）上顎全剔術 予め気管切閉をし，船管全身麻酔を 行い，輸血，輸液等全身管理の下に手街を与る，外頸 勳脈結紧後，顔面皮切は原則として，星野氏法により行 い,ウエーベル皮妇は術後下眼臉浮腫を残すので行わな い硬口蓋に腫瘍の漫潤なき場合は，口腔粘膜を残し， 後で煩粘膜と縫合し一次的に口腔への創面を開鎖する. デンケル氏部分切除は3例に行つたのみで，原則的には

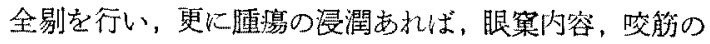

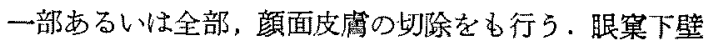
の破壊が若干あつても，眼窠下骨膛の及除去与れ《ば老分

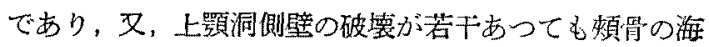

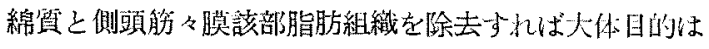

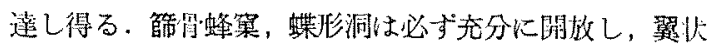

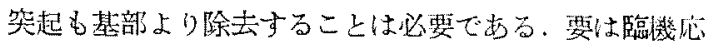

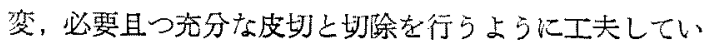
\$. 


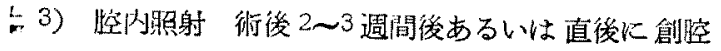

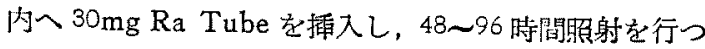
た. 今回発表以後の在例で徒, ${ }^{60} \mathrm{Co}$ Beads $(5 \mathrm{mc} \times 6)$, あるいは ${ }^{137} \mathrm{Cs}$ Tube (Ra $10 \mathrm{mg}$ equivalent $\times 5$ ) 等 に改良を加えている。

II）超広汎型あるいは手術拒否例の場合は，先に あげた術前炤射法を更に続け，または後方より1〜2門 追加貼射を行い，病篓線量が，5000レントゲン以上に 達するようにする。

III) 頸部リンパ節転移のある場合、できるだけ早 期に剔出ないし頸部漷清術を行つている、胸銷乳突笳は 除去するが，内頸静脈は多くの場合残乙得る．術前炤射 を行らこともあるが，原則的には行わず，予跨的彰清街 女行和ない.

\section{治 療 成 績}

治潦成䋶を論ずる場合，同じ進展方向と同し進展程度 のものについて比較されなければならない，先の際，前 述の分類が役古つのでするが，現在の段階では例数がな

第 7 表 上啱嵒患者 128 例の治療術式㓢 および進展程度別

\begin{tabular}{|c|c|c|c|c|}
\hline 人獄式 & 二者搠用 & 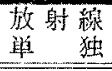 & 㯰 & 計 \\
\hline 比較的限局 & 18 & 16 & 5 & 39 \\
\hline 㲸 & 22 & 43 & 16 & 81 \\
\hline 超 広 沉 & 1 & 5 & 2 & 8 \\
\hline 合䚵 & 41 & 64 & 23 & 128 \\
\hline
\end{tabular}

拈少く，多くの区分を誐けて検討することが不可能であ る。しかし，前額面の進展方向別による生存慗仕大差羊 ないよらであり，前後軸では前後ともの型が生存率が低 いが，これは広汎型と共通しているので，今回は進展程 度差のみを考盛した，著者らが治澿を行つた症例のら ち，事故死（路疾以外の原因で死亡したるの）10例を 除いた128例について，治潦洔式別，進展程度別に区分 すると第7淩のよらになる。姑息的治潦に終つたものは 放置と見なした。

次にその夫々の区分について生存䲞を第 8 表に示す. 前表の生存率の推移を通臨すると，大体三群住分ける ことができる。

A群：限局型に三者併用を行つたるの 広沉型に三者併用を行つたるの 限局型に放射線単独を行つたもの

B群：広沨型に放射線単独を行つたもの 超広汎型に放射線単独を行つたもの

C群：超広沈型に三者併用を行つたもの

限局型，広沉型，超広汎型で放置したもの

即ち，限局型（比較的限局型）では放射線単独璙法に よつてもかなりよい成縝が得られているが，広汎型では 三者併用により初めて生存率を高めることがでさ，放置 例では型の别を問わず全て死亡することが判る。そこで この三群について，再び生存率とその母生存率の信頼限

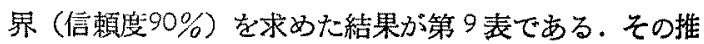
計学的公式は，例数 N中生存者 $\mathrm{K}$ むると

第 8 表 治療術式, 進展程度別にみた生存篎

\begin{tabular}{|c|c|c|c|c|c|c|c|c|c|c|c|c|c|c|c|c|}
\hline 区分 & （術前熙射 & 者 & $\begin{array}{c}\text { 供 } \\
\text { 全剔 }\end{array}$ & $\begin{array}{c}\text { 用 } \\
\text { - 腔内其 }\end{array}$ & 射) & 放 射 & 線 単 & 独 ( & 绎皮的 & & & 放 & & & 掼 & \\
\hline & 比较的限局 & 広 & 沉 & 超 㞤 & 沉 & 此較的限局 & 広 & 沉 & 超 & 広 汎 & 比校的 & 的限局 & 厇 & 沉 & 超広 & 讵 \\
\hline $\begin{array}{l}1 \text { 年以上 } \\
\text { 生存萃 }\end{array}$ & $14 / 1878 \% 0$ & $18 / 22$ & $82 \%$ & $0 / 1$ & $0 \%$ & $11 / 1669 \%$ & $23 / 43$ & $53 \%$ & $4 / 5$ & $80 \%$ & $1 / 5$ & $20 \%$ & $1 / 16$ & $0 \%$ & $0 / 2$ & $0 \%$ \\
\hline 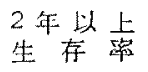 & $5 / 1145 \%$ & $7 / 15$ & $47 \%$ & $0 / 1$ & $0 \%$ & $7 / 1450 \%$ & $6 / 33$ & $18 \%$ & $1 / 4$ & $25 \%$ & $0 / 4$ & $0 \%$ & $0 / 7$ & $0 \%$ & $0 / 1$ & $0 \%$ \\
\hline $\begin{array}{l}3 \text { 年以上 } \\
\text { 生存率 }\end{array}$ & $4 / 10 \quad 40 \%$ & $3 / 9$ & $33 \%$ & $0 / 1$ & $0 \%$ & $4 / 1136 \%$ & $3 / 25$ & $12 \%$ & $0 / 3$ & $0 \%$ & $0 / 4$ & $0 \%$ & o/ 5 & $0 \%$ & $0 / 1$ & $0 \%$ \\
\hline $\begin{array}{l}4 \text { 年以上 } \\
\text { 生存 }\end{array}$ & $3 / 560 \%$ & $2 / 7$ & $29 \%$ & $0 / 1$ & $0 \%$ & $3 / 560 \%$ & $3 / 16$ & $19 \%$ & $0 / 1$ & $0 \%$ & $0 / 3$ & $0 \%$ & o/ 3 & $0 \%$ & $0 / 1$ & $0 \%$ \\
\hline $\begin{array}{l}5 \text { 年以上 } \\
\text { 生存就 }\end{array}$ & 3/ $560 \%$ & $1 / 2$ & $50 \%$ & $0 / 1$ & $0 \%$ & $1 / 250 \%$ & $0 / 3$ & $0 \%$ & $0 / 1$ & $0 \%$ & $0 / 1$ & $0 \%$ & $0 / 1$ & $0 \%$ & $0 / 0$ & $0 \%$ \\
\hline
\end{tabular}




$$
\text { 母百分率の上限 …… } \mathrm{P}_{\mathrm{U}}=\frac{\mathrm{n}_{1} \mathrm{~F}_{\mathrm{n}_{2}}^{\mathrm{n}_{1}}(0.05)}{\mathrm{n}_{1} \mathrm{~F}_{\mathrm{n}_{2}}^{\mathrm{n}_{1}}(0.05)+\mathrm{n}_{2}}
$$

$$
\text { 母百分率の下限 …… } \mathrm{P}_{\mathrm{L}}=\frac{\mathrm{n}_{2}^{\prime}}{\mathrm{n}_{\mathbf{1}} \mathrm{F}_{\mathrm{n}_{2}}^{\mathrm{n}_{1}}(0,05)+\mathrm{n}_{2}^{\prime}}
$$

$$
\text { 但し } \begin{aligned}
\mathrm{n}_{1} & =2(\mathrm{~K}+1) \\
\mathrm{n}_{2} & =2(\mathrm{~N}-\mathrm{K}) \\
\mathrm{n}_{1}{ }^{\prime} & =2(\mathrm{~N}-\mathrm{K}+1) \\
\mathrm{n}_{2}{ }^{\prime} & =2 \mathrm{~K} \\
\mathrm{~F} & (0.05) \text { は危険率 } 5 \% \text { 值 }
\end{aligned}
$$

\begin{tabular}{|c|c|c|c|c|}
\hline & 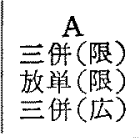 & $\begin{array}{c}\text { B } \\
\text { 放単(㕕) } \\
\text { 放単(超広) }\end{array}$ & 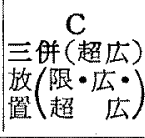 & $\begin{array}{l}\text { 蕫者らが治 } \\
\text { 尞したもの } \\
\left(\begin{array}{l}\text { 事敬死を } \\
\text { 除く }\end{array}\right)\end{array}$ \\
\hline $\begin{array}{l}1 \text { 年以上 } \\
\text { 生存漟 }\end{array}$ & $\mid \begin{array}{l}44 / 56 \quad 78 \% \\
(67 \sim 86 \%)\end{array}$ & $\left|\begin{array}{ll}27 / 48 & 56 \% \\
(38 \sim 69 \%)\end{array}\right|$ & $\left(\begin{array}{r}1 / 24 \quad 4 \% \\
(2 \sim 18 \%)\end{array}\right.$ & \\
\hline $\begin{array}{l}2 \text { 年以上 } \\
\text { 生存率 }\end{array}$ & $\begin{array}{l}19 / 4048 \% \\
(34 \sim 61 \%)\end{array}$ & $\begin{array}{r}7 / 3719 \% \\
(9 \sim 33 \%)\end{array}$ & $\left(\begin{array}{c}0 / 130 \% \\
(0 \sim 17 \%)\end{array}\right.$ & $\begin{array}{l}26 / 7833 \% \\
(25 \sim 43 \%)\end{array}$ \\
\hline $\begin{array}{l}3 \text { 年以上 } \\
\text { 生存离 }\end{array}$ & $\begin{array}{l}11 / 2938 \% \\
(23 \sim 55 \%)\end{array}$ & $\begin{array}{r}3 / 28 \quad 11 \% \\
(3 \sim 25 \%)\end{array}$ & $\frac{0 / 110 \%}{(\longrightarrow)}$ & $\begin{array}{l}14 / 58 \quad 24 \% \\
(15 \sim 35 \%)\end{array}$ \\
\hline $\begin{array}{l}4 \text { 年以上 } \\
\text { 生存率 }\end{array}$ & $\begin{array}{r}8 / 1747 \% \\
(25 \sim 68 \%)\end{array}$ & $\begin{array}{r}3 / 1718 \% \\
(5 \sim 40 \%)\end{array}$ & $0180 \%$ & $\begin{array}{l}11 / 3531 \% \\
(18 \sim 47 \%)\end{array}$ \\
\hline $\begin{array}{l}5 \text { 年以上 } \\
\text { 存率 }\end{array}$ & $5 /(\stackrel{956 \%}{\longrightarrow}$ & $\%\left({ }^{\circ} \quad 0 \%\right.$ & $0 / 30 \%$ & $\begin{array}{l}5 / 1436 \% \\
(\longrightarrow\end{array}$ \\
\hline
\end{tabular}

第9第 治寮術式で三群に分けた場合の生存率 （）内はその母百分率の信頼限界

第9表によると，A 群では 3 年以上生存率 38\%で, その母百分率は 23〜55\%にあることが期待される。 B 群の3 年以上生存率 $11 \%$ ，铂分率 $3 \sim 25 \%$ 下比 し明らか有意差を示している。しかしB群に批いても 1 年生存率 $56 \%$ ，その母百分率 38～69\% となり，放置 群に比し延命効果の大きいことが期待されるのである.

第9表の右列仙挙げたものは，当院で治療を受けたも の（但し事故死を除く）105例についての生存率および その母百分率の信頼限界である。これによると，1年 以上生存率 $68 \%, 3$ 年以上生存率 $24 \%, 5$ 年以上生存率 $36 \%$ の成緙が得られた，例数の関係で 3 年より 5 年の方 が高率に出ているが，大体の見通しでは 5 年生存率（治 痛率と見做してよい）30\%位が期待できるようである。 著者らがもつとも強調したいのはこの点であり，この成 繦が得られたのは，耳鼻科，放射線科が䇣密な連絡の 上，合議で治蹽方針を定め，それに従つて終始一貫努力 を続けてきた賜である。

申すまですなく，著者らは以上の成績に满足している
わけではなくて，更に治疮摔向上を目指して種々努力し ているが，今日の医療找術のみをむつてしてはな报越え 難い限界のあることを認めずにはいられない。

1）上㽬癌患者 161 名を猃断分頪し，その中，115名 は著者らの計西した沿療方針を遂行し，全例経過㓋案が できたが，23名は放置あるい性姑息的治療に終つた。

2）X線所見に上り進展䇺囲を分類し，な括手術を行 つたものについては，必要に応じて適宜補正した。

3）分類は原発部位によって6種類に分け，上顎洞原 発のものについては進展方向別に前類面で 5 種類（上内 方，上側方，下内方，下側方，洞中心），前後軸では， 4 種類（前後になし，前方，後方，前後とも）を設けた。 進展程度に上り限局，比較的限局，広沉，超広沉の 4 種 類を設けた。 又，転移の有無により区分した。

4）上䫇癌は上顎洞原発型が $98 \%$ を占め，比較的限 局 $33 \%$ ，広沉型 $61 \%$ ，上内方型 $36 \%$ ，洞中心型 $39 \%$ が 多く，転移は少くとも $16 \%$ に認め，上内方，洞中心， 後方型に多発してみら就た。

5）治療方針は術前照射，上颔全剔術，腔内照射の三 者侀用方法を探用し，手術不能例，手術拒否例では放射 線単独褶法定行つた。

6）治療成績についてみると，三者阙用痖法を行つた 比較的限局型，広沉型，ならびに放射線単独療法を行っ た比較的限局型の 3 年生存率は，夫夕 $4 / 10(40 \%), 3 / 9$ (33\%)，4/11(36\%) と大体 30４0\% の成績を示し， 放射線単独療法を行つた広沉型では，3/25(12\%)の3 年生存率を示している。従つて当院で著㨋らが治療を 行つた全例の3 年生存客休 $14 / 58(24 \%) ， 5$ 年生存率は 5/14 (36\%) であつた.

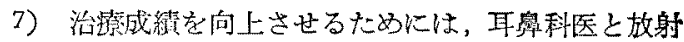
線医との緊密な協同体制が必要である。

\section{文献}

1) Sibileau, P.: Bull. Soc. Chir. Paris 32: 517, 1905. 2) Öhngren L.O.G.: Acta Otolaryng. Stochh., Suppl.19: 1933. 3 3) Brun: Pract. Otolaryng. 18: 171，1956。 4) 奥田稳：耳㶼科，33:917， 1961.5）浅井良三：第一回頭頸部腫場研究会，於

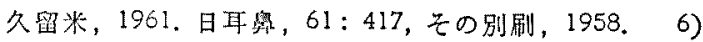
河田政一：日耳厸，65：385，之の別別，1962。7) Baclesse, F.: Ann, d' Otolaryng. 69: 465, 1952. 8) Dodd, G.D.: Radiology 72:379, 1959.9 9) 浜 崎靖：日医放雑誌，21：30,1961。10) 塚本憲甫： 
日医放雑誌，17：435，1957，11）藤森啺路：日耳稛， 65:383, その別刷，1962.12) 北村武：日耳奥，65: 384, 矢の别刷, 1962. 13) 山下久堆: 日耳率, 65: 38, 1962. 14) Larsson, L.G. \& G. Märtensson: Acta Radiolog. 42：147, 1954, 15) 酒井俊一：日 耳舀，62:2192, 1959.

稆を終るに臨み，御指導御校閲を睗つた恩所 長谷川离敏教授，立入弘教授に梁謝します 仵
せて御協力を頂いた，当耳專咽喉科，放射線 科，第二外科麻午班の各先生方に感謝致しま t)

本論文の要旨は，第 23 回近裁耳拿咽喉科学 会第 114 回日本耳舜咽喉科学会大阪地方会蛒よ び第2 21 回日本癌学会繶会等において発表した。

（原舷到着＝昭和 37.10 .16 日）

\section{耳鳴専門治療薬}

末

錠昰徒

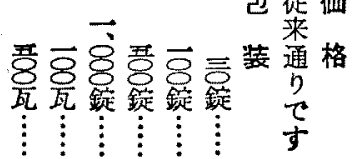

$\stackrel{\vdots}{\vdots} \dot{\vdots} \doteq$

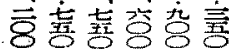

䑤角角角

耳作殊行低脸性神高

鳴角機血諸疾経血適

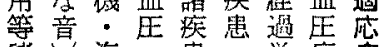

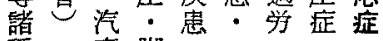
種車脚・ $x$ のス・気フ二更動 原トエ・レェ年胀 因、場飄ルル期硬 化等音ギ病症化 小のの鿊 万副特我! 内熱。
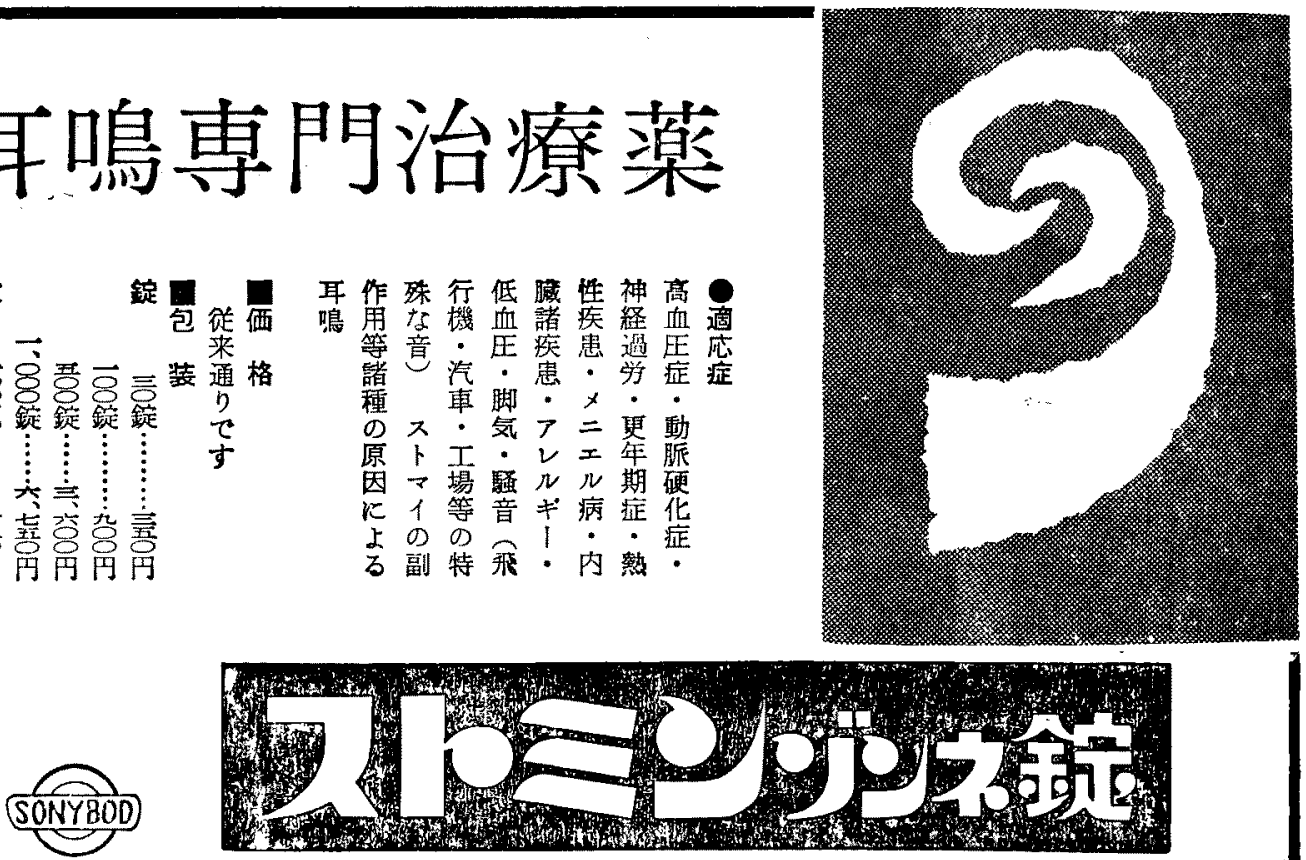

(旧名ストップミン錠)

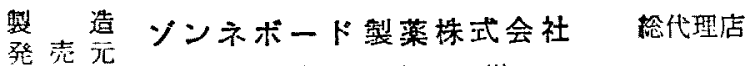

鳥居薬品㧣 式会社 東宗 - If 川

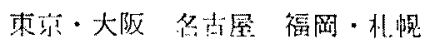

